\title{
APPLICATION OF TRANSLATION RUBRICS IN LITERARY TRANSLATION CLASSES
}

\author{
Özlem Şahin Soy*
}

\begin{abstract}
Literary translation, although under different titles, is included in the curricula of most of the education institutions that have Translation studies departments. Assessing the competence of the students in literary translation classes is generally done through codes of practice since most of the rubrics on translation focus on issues such as grasp of information, ease of translation, use of language, grammar rules etc. Apart from this, literary evaluation requires a deeper assessment for each genre depending on its specific properties of form and content. This paper aims to discuss the use of translation assessment rubrics for literary translation courses and investigate whether a more improved style for each genre of literature can be proposed for this purpose. To this end, general approaches to assessment of translation competence and rubrics offered by different institutions are surveyed and their applicability to literary translation courses discussed. In the end, a comprehensive rubric for literary translation courses will be presented.
\end{abstract}

Key words: translation training, assessment, literary translation, rubric

\section{Introduction}

Translation training, the subfield of Applied Translation Studies as pointed out in the well-known "map" of Holmes (1972), is developing rapidly since translation has been acknowledged as an area of academic research both in the East and the West since the 1980s. It has also become a professional area demanding sophisticated education at higher levels, thereby resulting in discussions, on the assessment of translation activities to be held in classrooms and making it possible for many translation assessment rubrics to be created for this purpose.

Translation Quality Assessment and Translation Evaluation have developed as two different sub-fields of Applied Translation Studies. There are various approaches adopted by professional institutions and academia to the subject all of which share two basic purposes: to classify the quality of translation and to evaluate it objectively. To put the subject in a scientific frame, scholars and professional companies use various rubrics and evaluation criteria that make

\footnotetext{
* Assist. Prof. Dr. at Atılım University, Department of Translation and Interpretation, e-mail: ozlem.sahin@atilim.edu.tr.
} 
up their style guides. It is also possible to find out numerous similar translation rubrics and evaluation forms that basically share common basic items in their lists, such as grasp of information, coherence of translation, use of grammar, cultural awareness, etc. In order to avoid a conceptual contradiction, first of all, translation quality assessment and assessment of student performance in practice courses need to be handled by underlining the different meaning of the term "assessment" in each case.

\section{Previous research in the field}

This paper focuses on the assessment done in translation courses since most of the rubrics used for the assessment of translation practice are prepared for non-literary texts and, hence, is not comprehensive enough to cover the main items necessary for the evaluation of translated literary texts. As McAlester states, "in actual fact, we find that methods vary considerably between one accredited body and another, between one university and another, even between departments of the same university, indeed even between colleagues in the same department" (McAlester 2000: 230-231). This explanation appears to be valid for the case in Turkey as well. Likewise, there is no standard type of assessment used in most universities and departments, or even among colleagues from the same department for that matter. It appears that, generally, a holistic approach is adopted by the lecturers who mostly have a literary education background.

It is possible to see that the general approaches to the assessment of translation have varied since the 1990s and there are outstanding studies by scholars such as Gile (1995), Kussmaul (1995), House (1997), Melis \& Albir (2001) and Garant (2009) all of whom have contributed to the theory of translation assessment as a general subject in translation studies. A few, such as Mikel Garant, have addressed the assessment process in academic translation programs. In his study entitled "A case for holistic translation assessment", Garant presents a linear study of assessment practices in the English translation department of the University of Helsinki. After discussing the general approaches to assessment, Garant exemplifies the generally accepted grading methods in this department, and his comments on the holistic grading tendency of the evaluators in the department are similar to those of lecturers in similar departments within Universities in Turkey. He discusses the validity, reliability, objectivity and practicality of holistic grading approach in translator education followed by an example of Waddington's (2001) empirical study in which error analysis and the holistic approach are compared among 64 sophomore students. Waddington's study reveals that error analysis and holistic assessment yield the same results. Although there are such examples discussing the validity of holistic assessment, still the questions remain related to the objectivity of the method. For this reason, a comprehensive approach should be discussed in detail, one which includes 
elements related to the assessment of a translation of a literary text. The method based on this approach should not only cover the evaluation of transference of literary, linguistic, semantic, syntactic and cultural elements in the text, but also it should be practical for the evaluator.

\section{Analysis}

This approach aims to present such a comprehensive and practical model for the assessment of students in literary translation courses. In this model, Werner Koller's frame of equivalence, Raymond van den Broeck's threestep descriptive translation criticism model and Julianne House's model for evaluating translations are applied in order to create a detailed rubric for literary translation practices.

Koller, one of the most prominent German scholars working in the field of translation studies, refers to translational equivalence as an argument against the theories of general untranslatability. Koller's (1979) Einführung in die Übersetzungswissenschaft ('Introduction into the Science of Translation') is a detailed study of the concept of equivalence and correspondence. For him, correspondence involves the comparison of two language systems where differences and similarities are described contrastively, whereas equivalence deals with equivalent items in specific ST-TT pairs and contexts (Koller 1979). Koller's frame of equivalence can be useful in forming a model for the evaluation of literary translation because it presents an overarching approach on the understanding of the term "equivalence". He uses the terms "denotative equivalence", "connotative equivalence", "text-normative equivalence", "pragmatic equivalence" and "formal aesthetic equivalence" in his study (1995), in which he focused on the types of equivalence. Equivalence is a central concept in translation studies, having various dimensions as discussed by famous scholars such as Vinay and Darbalnet (1958), Jakobson (1959), Nida and Taber (1969), Catford (1965), House (1997), Koller (1979), Newmark (1981), Baker (1992), and, finally Pym (2010). Although equivalence is a controversial term that has recently been labelled as old-fashioned, it can still be accepted as a basic starting point for translation evaluation and assessment. The terms used by Koller to explain the different dimensions of equivalence are quite comprehensive for the evaluation of literary translations since they cover the extralinguistic content of the text, lexical choice, form and aesthetics of the text, text types and an analysis of the receiver of the text. Therefore, this approach can be useful for a general evaluative rubric of literary translation practices.

In addition to Koller's approach to equivalence, Julianne House's "Model for Evaluating Translations" can be useful to set an all-inclusive evaluation for literary translation. House has a very basic definition of translation as "the 
replacement of a text in the target language" (House 2015: 63) that can be taken as the starting point of evaluation.

The use of the word "quality", while speaking about the evaluation of literary texts appears to be quite irrelevant, since the quality of a literary work cannot be discussed in objective terms. However, though depending on personal preference, there is still a simple formula for the success in literature which can be explained as the creation of a combination of form and content in such a way as to create an aesthetic value. In this frame, House's revised model of "Translation Quality Assessment" (1997) will be referred to in the evaluation of the individual function of the text. In this model, House focuses on the relationship between the source and the target texts in order to categorize the overt and the covert errors of translation through an analysis of register, genre, field, tenor and mode:

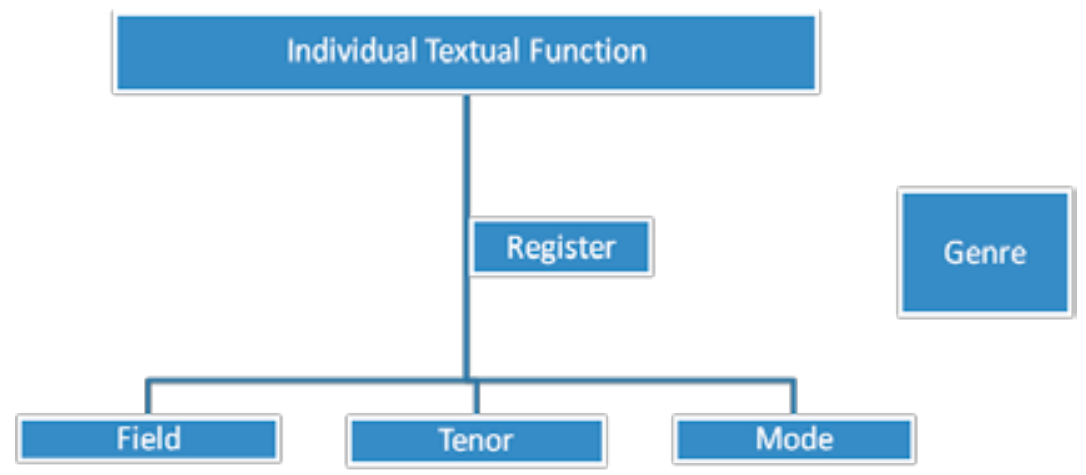

\section{Language/Text}

(House 1997)

House underlines "socio-cultural differences in expectation norms and stylistic conventions between the source and target linguistic-cultural communities" in relation to the concept of "cultural filter" (House 1997: 68). This term may also be useful while preparing evaluation criteria for literary translation courses since it is important to point out if the student understands socio-cultural differences and offers solution suggestions. In her work, she offers subcategories for overt and covert errors in her work that can also be useful for a fair evaluation of in-class practices. For House, overtly erroneous errors have one or more of the following properties:

1. Not translated

2. Slight Change in Meaning

3. Significant Change in Meaning 


\section{Distortion of Meaning}

5. Breach of the Source Language System

6. Creative Translation

7. Cultural Filtering

(House 1997: 33-52)

Each of these items is worth considering for an overall evaluation of a translated literary text. On the other hand, "covertly erroneous errors" are described as any mismatches along the functional dimensions of the text. To her, covert errors that result from a mismatch on a particular situational dimension are about socio-cultural norms which means "norm-conditioned expectations generated by the text", the differences between the two language systems and addition of a secondary function to the text. Thus, it appears that covert errors might be understood as a result of a much more descriptive, indepth analysis of the translated texts. In this respect, the previous holistic approach to the assessment of literary translations by students, as mentioned earlier, is rather more concerned with covert erroneous errors, indeed. Such a qualitative analysis might be an important criterion to understand students' basic understanding of the text, language and culture.

The third approach that is benefited from for the translation evaluation rubric is Raymond van den Broeck's descriptive systemic analysis. Broeck, in his article "Second Thoughts on Translation Criticism" (1985), upon observing the lack of attention in scientific studies on the area of translation criticism in Western Europe, set out to establish a systemic model for this subject. His approach, aiming to turn translation criticism from subjectivity to objectivity, stands as a cornerstone in Translation Studies. The model proposed by Broeck involves a systematic description of a comparative analysis of the source and target texts. U until 1980s, translation criticism was done by a random set of individuals from literary critics to readers and editors, without the application of any preset criteria. His model filled this gap by suggesting a systematic comparative analysis of the source and target texts (TT) to get avoid subjective comments on translated literary texts. As a result, translators' choices and the translation process itself have received more significance along with other cultural and social factors involved in the process. The purpose of the comparative analysis in this model is to ascertain the degree of factual equivalence between the source and target texts. The term "adequate translation" described by Gideon Toury is also used by Broeck, however, he claims that adequate translation is not an actual text in essence, but a hypothetical reconstruction of the textual relations and functions of the source text (ST). The comparison of the ST and TT should also take into account the occurrence of shifts of expression in the TT (Broeck 1985: 57-8). 
According to Broeck, the comparison of a TT with its ST is composed of 3 stages:

1. A systemic analysis of the ST including phonic, lexical, and syntactic components, language varieties, figures of rhetoric, narrative and poetic structures, elements of text convention (text sequences, punctuation, italicizing, etc.), thematic elements, and so on.

2. A comparison of the TT elements in relation to these textemes: taking into account the various shifts (or deviations) with respect to the ST.

3. A generalizing description of the differences between the actual target text/source text equivalence and the adequate translation, on the basis of the comparison of the textemes (Broeck 1985: 58).

This model offers a broad frame for evaluating literary texts that is also needed by lecturers of literary translation courses. Likewise, as seen in the starting comments by Broeck, a subjective approach should be applied by lecturers instead of a general assessment of the translation practice. This approach should be a step-by-step analysis of the work done by the student including the research process, since students should learn that literary translation is a toilsome process and cannot be accomplished without understanding certain parameters such as the author's life, general characteristics of the genre in which the work is written, the period in which the author has created the work, and other works by the same author.

\begin{tabular}{|c|c|c|c|c|c|c|c|}
\hline \multicolumn{8}{|c|}{ PART I: Literary Elements } \\
\hline \multicolumn{2}{|c|}{ Evaluation Criteria } & \multicolumn{5}{|c|}{ Assessment } & \multirow{2}{*}{ Score } \\
\hline & & Excellent & Proficient & Developing & Attempting & Not Grasped & \\
\hline \multirow{10}{*}{$\begin{array}{l}\text { Comprehension of } \\
\text { the Source text } / \text { } \\
\text { Recreation of the } \\
\text { same: }\end{array}$} & Genre & & & & & & \\
\hline & Sub-genre & & & & & & \\
\hline & Plot & & & & & & \\
\hline & Characterization & & & & & & \\
\hline & Point of View & & & & & & \\
\hline & $\begin{array}{l}\text { Setting (Time and } \\
\text { Place) }\end{array}$ & & & & & & \\
\hline & $\begin{array}{l}\text { Figurative } \\
\text { language }\end{array}$ & & & & & & \\
\hline & Imagery & & & & & & \\
\hline & Symbolism & & & & & & \\
\hline & $\begin{array}{l}\text { Tone and } \\
\text { Atmosphere }\end{array}$ & & & & & & \\
\hline
\end{tabular}


PART II: Comparison of Source Text and Target Text

\begin{tabular}{|c|c|c|c|c|c|c|}
\hline Overtly Erroneous Errors & $\begin{array}{l}\text { Excellent } \\
5 \% \text { or } \\
\text { less of } \\
\text { the text }\end{array}$ & $\begin{array}{l}\text { Proficient } \\
5-25 \% \\
\text { of the text }\end{array}$ & $\begin{array}{l}\text { Developing } \\
25-50 \% \text { of } \\
\text { the text }\end{array}$ & $\begin{array}{l}\text { Attempting } \\
50-75 \% \\
\text { of the text }\end{array}$ & $\begin{array}{l}\text { Not } \\
\text { Grasped } \\
75-100 \% \\
\text { of the text }\end{array}$ & Score \\
\hline \multicolumn{7}{|l|}{ Not translated } \\
\hline \multicolumn{7}{|l|}{ Slight change in meaning } \\
\hline \multicolumn{7}{|l|}{ Significant change in meaning } \\
\hline \multicolumn{7}{|l|}{ Distortion of meaning } \\
\hline \multicolumn{7}{|l|}{ Breach of the SL System } \\
\hline \multicolumn{7}{|l|}{ Creative translation } \\
\hline \multicolumn{7}{|l|}{ Cultural filtering } \\
\hline Covert Erroneous Errors & $\begin{array}{l}\text { Excellent } \\
5 \% \text { or } \\
\text { less of } \\
\text { the text }\end{array}$ & $\begin{array}{l}\text { Proficient } 5 \\
-25 \% \text { of the } \\
\text { text }\end{array}$ & $\begin{array}{l}\text { Developing } \\
25-50 \% \text { of } \\
\text { the text }\end{array}$ & $\begin{array}{l}\text { Attempting } 50- \\
75 \% \text { of the text }\end{array}$ & $\begin{array}{l}\text { Not } \\
\text { Grasped } \\
75-100 \% \\
\text { of the text }\end{array}$ & Score \\
\hline \multicolumn{7}{|l|}{ Norm-conditioned expectations } \\
\hline \multicolumn{7}{|c|}{$\begin{array}{l}\text { The differences between the two language } \\
\text { systems }\end{array}$} \\
\hline \multicolumn{7}{|c|}{$\begin{array}{l}\text { Addition of a secondary function to the } \\
\text { text }\end{array}$} \\
\hline \multicolumn{7}{|c|}{ PART III: Evaluation of Various Levels of Equivalence: } \\
\hline & $\begin{array}{l}\text { Excellent } \\
5 \% \text { or } \\
\text { less of } \\
\text { the text }\end{array}$ & $\begin{array}{l}\text { Proficient } \\
5-25 \% \\
\text { of the text }\end{array}$ & $\begin{array}{l}\text { Developing } \\
25-50 \% \text { of } \\
\text { the text }\end{array}$ & $\begin{array}{l}\text { Attempting } \\
50-75 \% \text { of } \\
\text { the text }\end{array}$ & $\begin{array}{l}\text { Not } \\
\text { Grasped } \\
75-100 \% \\
\text { of the text }\end{array}$ & Score \\
\hline \multicolumn{7}{|l|}{ Denotative Equivalence } \\
\hline \multicolumn{7}{|l|}{ Connotative Equivalence } \\
\hline \multicolumn{7}{|l|}{ Text-normative Equivalence } \\
\hline \multicolumn{7}{|l|}{ Pragmatic Equivalence } \\
\hline Formal Aesthetic Equivalence & & & & & & \\
\hline
\end{tabular}

The first part of the rubric aims to evaluate if the qualities peculiar to the specific genre or sub-genre observed in the ST are kept in the TTs or not. If there are any changes in the plot development due to lack of understanding and/or voluntary or optional changes in the plot, the structure should be evaluated according to the given task. Point of view and characterization should be observed carefully since they are both highly influential on the style of the author. For example, if there is an alteration in point of view, that means the student is probably unaware of the importance of the subject in literary texts. Creativity and cultural awareness of the student can be assessed through observation of figurative language, symbolism and imagery. The second part of the rubric is 
more specifically about translation competence and perfection. In this part, the ST and the TT should be investigated closely in order to find out if there are any segments that are either not translated, mistranslated, culturally misunderstood, or not transferred intentionally. At this point, if the student has changed the function of the text, for example from adult literature into a text for children, they should also be assessed according to the given task. The third part of the evaluation deals with the asked, intended and achieved equivalence, again according to the type of the task given by the lecturer. The following can be evaluated in this part of the rubric; the extralinguistic content of the ST and its recreation in the TT, lexical choices of the TT author and student's grasp of these choices, student's understanding of the text type, and the audience of the text, general formal and aesthetics of the ST and the TT.

\section{Conclusion}

This article has offered a brief overview of a Rubric to evaluate students' practices in literary translation courses. Due to the lack of systematic criteria in this field, the paper proposes a general rubric for lecturers and instructors that may help their evaluation process. This approach may yield similar results to those of a holistic assessment; however, it is an alternative for better support and improvement of the students, in their learning environment. Having such a comprehensive rubric to include the key elements that are important for literature and translation studies may also create confidence on the part of the student, since they will have an idea about the assessment and expectations.

\section{References:}

Al-Qinai 2000: Al-Qinai J. Translation Quality Assessment: Strategies, Parametres and Procedures. Meta XLV 3: 497-519.

Baker 1992: Baker M. In Other Words: A Coursebook on Translation. London; New York: Routledge.

Broeck 1985: Broeck R. Van den. Second Thoughts on Translation Criticism. - In: Hermans T. (Ed.) The Manipulation of Literature. Studies in Literary Translation. New York: St. Martins Press. 54-63.

Catford 1965: Catford J. C. A Linguistic Theory of Translation. London: Oxford University Press.

Garant 2009: Garant M. A Case for Holistic Translation Assessment. - In: Kalliokoski J., Nikko T., Pyäniemi S., S. Shore (eds.) A Fin LA-e Soveltavan kielitieen tutkimuksia / No. 1. 5-17 <http://file:///C:/Users/\%C3\%96zlem\%20\%C5\%9Eahin\%20Soy/ Downloads/2612-1-6206-1-10-20100115\%20(1).pdf> [Accessed 5 April 2017]

Gile 1995: Gile D. Basic Concepts and Models for Interpreters and Translator Training. Benjamins Translation Library 8 Amsterdam: Benjamins. 
Göpferich, Jääskeläinen 2009: Göpferich S., R. Jääskeläinen. Process Research into the Development of Translation Competence: Where Are We, and Where Do We Need to Go? - Across Languages and Cultures. 10: 169-191.

Holmes 1988/2000: Holmes J. S. The Name and Nature of Translation Studies. - In: Venuti L. (ed). The Translation Studies Reader. London and New York: Routledge, 2000: 172185.

House 1997: House J. Translation Quality Assessment: A Model Revisited. Tubingen: Narr.

House 2009: House J. Translation. Oxford: Oxford University Press.

House 2015: House J. Translation Quality Assessment: Past and Present. Londres: Routledge.

Jacobson 1959: Jacobson R. On Linguistic Aspects of Translation. - In: Brower R. A. (ed.). On Translation. Harvard University Press. 232-239; repr. - In: Venuti L. (ed.). The Translation Studies Reader. Routledge, 2000. 113-118.

Kussmaul 1995: Kussmaul P. Training the Translator. Benjamins Translation Library 10. Amsterdam: Benjamins.

Koller 1979: Koller W. Einführung in die Übersetzungswissenschaft (Introduction into the Science of Translation). Heidelberg: Quelle and Meyer.

Koller 1995: Koller W. The Concept of Equivalence and the Object of Translation Studies. - Target 7: 191-222.

McAlester 2000: McAlester G. The Evaluation of Translation into a Foreign Language. In: Schäffner C., B. Adab (eds.). Developing Translation. Benjamin's Translation Library. Amsterdam. 229-241.

Melis, Albir 2001: Melis N. M., A. H. Albir. Assessment in Translation Studies: Research Needs. - Meta. 46 (2), 272-287.

Munday, J. 2000: Munday J. Introducing Translation Studies. London and New York: Routledge.

Newmark 1981: Newmark P. Approaches to Translation. New York: Pergamon Press.

Nida, Taber 1969: Nida E., C. R. Taber. The Theory and Practice of Translation. Leiden: E.J. Brill.

Pym 2010: Pym A.D. Exploring Translation Theories. London \& New York.

Schäffner 1997: Schäffner C. From Good to Functionally Appropriate: Assessing Translation Quality. - Current Issues in Language and Society. 4(1), 1-5.

Waddington 2001: Waddington C. Different Methods of Evaluating Translations: The Question of Validity. - Meta. 46(2), 326-344.

Williams 2009: Williams M. Translation Quality Assessment. Ottawa: University of Ottawa Press.

Vinay, Jean 1958/1989: Vinay J., D. Jean. Translation Procedures. trans. Andrew Chesterman. - In: Chesterman A. (ed.). Readings in Translation Theory. Helsinki: Oy Finn Lectura. 61-69.

Vinay, Jean 1958/1995: Vinay J., D. Jean. Comparative Stylistics of French and English. A Methodology for Translation. Trans. Sager J. C., M.-J. Hamel. Amsterdam and Philadelphia: John Benjamins. 